\title{
Health Risk Assessment for the Exposure of Workers to BTEX at the Gasoline Stations
}

\section{*NGUYEN THANH GIAO; PHAN KIM ANH; HUYNH THI HONG NHIEN}

\author{
College of Environment and Natural Resources, Can Tho University, Vietnam \\ *Corresponding Author Email: ntgiao@ctu.edu.vn
}

\begin{abstract}
The study was conducted to assess the health risks of workers due to exposure to toxic gases including benzene, toluene, ethylbenzene, m, p-xylene, o-xylene, formaldehyde and acetaldehyde at gasoline retail stations. In this study, data on the concentrations of the toxic gases were collected from the previously published studies in the qualified scientific journals. The health risk assessment was followed by the process of the United States Environment Protection Agency (U.S. EPA). The results show that the concentrations of benzene, toluene, ethylbenzene, m, p-xylene, o-xylene, formaldehyde, and acetaldehyde were in the range of 12.40 - 357.5, $12.47-574.17,2.05-156.5,4.57-218,2.36-77.04$, $3.64-153.93$ and $1.27-27.83 \mu \mathrm{g} / \mathrm{m}^{3}$, respectively. Life time cancer risk for gasoline station workers due to exposure to benzene, ethylbenzene, formaldehyde, and acetaldehyde was calculated in the ranges of $2.13 \times 10^{-5}-6.14 \times 10^{-4}, 4.96 \times 10^{-}$ $7-3.79 \times 10^{-5}, 4.81 \times 10^{-6}-2.03 \times 10^{-4}$, and $7.99 \times 10^{-7}-1.75 \times 10^{-5}$, respectively. For non-carcinogenic compounds, the hazard index due to benzene, toluene, $\mathrm{m}$, p-xylene, o-xylene were respectively in the range of $0.13-3.81,7.97 \times 10-4-0.04$, $0.01-0.70$ and $0.01-0.25$. The findings revealed that there is high risk of cancer and non-cancer for the workers working at the gasolines stations if they are not taking good preventive measures. The calculation showed that the limit levels of benzene, toluene, ethylbenzene, xylene, formaldehyde and acetaldehyde should be reduced to $5.82 \times 10^{-4}, 15.64,4.13 \times 10^{-}$ ${ }^{3}, 0.31,7.57 \times 10^{-4}$ and $1.59 \times 10^{-3} \mathrm{mg} / \mathrm{m}^{3}$, respectively to meet the safety levels for the workers at the gasoline stations.
\end{abstract}

DOI: https://dx.doi.org/10.4314/jasem.v25i1.10

Copyright: Copyright (C) 2021 Giao et al. This is an open access article distributed under the Creative Commons Attribution License (CCL), which permits unrestricted use, distribution, and reproduction in any medium, provided the original work is properly cited.

Dates: Received: 02 October 2020; Revised: 26 November 2020; Accepted: 12 December 2020

Keywords: benzene, toluene, ethylbenzene, xylene, formaldehyde, acetaldehyde, life-time cancer risk, health

Pollution of BTEX (including benzene, toluene, ethylbenzene, xylene) and carbonyl compounds (such as formaldehyde, acetaldehyde) in the air is a common problem and has been received much attention since BTEX and carbonyl compounds are mutagenic or carcinogenic (Possanzini et al., 2002). Benzene $\left(\mathrm{C}_{6} \mathrm{H}_{6}\right)$ is widely used in industries (Yardley-Jones et al., 1991) and is a carcinogenic compound for humans and animals (Rana and Verma, 2005). Toluene $\left(\mathrm{C}_{6} \mathrm{H}_{5} \mathrm{CH}_{3}\right)$ is a benzene derivative, less volatile than benzene, soluble in many substances, used as solvent (YardleyJones et al., 1991). Ethylbenzene is an organic compound with the formula $\mathrm{C}_{6} \mathrm{H}_{5} \mathrm{CH}_{2} \mathrm{CH}_{3}$. It is a highly flammable, colorless liquid with an odor similar to that of gasoline. Ethylbenzene is produced in on a large scale by combining benzene and ethylene in an acid-catalyzed chemical reaction. The longer-term toxicity and carcinogenicity are ambiguous. Eye and throat sensitivity can occur when high level exposure to ethylbenzene in the air occurs. At higher level exposure, ethylbenzene can cause dizziness. Xylene $\left(\mathrm{C}_{6} \mathrm{H}_{4}\left(\mathrm{CH}_{3}\right)_{2}\right)$ is an aromatic hydrocarbon widely used in industry and medical technology as a solvent. It is a colorless, sweet-smelling liquid or gas occurring naturally in petroleum, coal and wood tar. It is found in small amounts in airplane fuel, gasoline and cigarette smoke. Exposure to xylene can occur via inhalation, ingestion, eye or skin contact. It is primarily metabolized in the liver by oxidation of a methyl group and conjugation with glycine to yield methyl hippuric acid, which is excreted in the urine. Xylene causes health effects via inhalation, ingestion, eye or skin contact. The main effect of inhaling xylene vapor is depression of the central nervous system, with symptoms such as headache, dizziness, nausea and vomiting (Kandyala et al., 2010). Acetaldehyde and formaldehyde are the most common compounds in the carbonyl group, and are in turn the products of ethanol and methanol oxidation (Dutta et al., 2009). These two compounds are considered secondary pollutants because they can be converted into ozone $\left(\mathrm{O}_{3}\right)$ and peroxyacetyl nitrate (PAN) in the air. Mild exposure to acetadehyde and formaldehyde can irritate the eyes, throat and respiratory tract in humans. Several other studies demonstrated that respiration in the presence of formaldehyde and acetaldehyde causes squamous cell carcinoma or adenocarcinoma in humans (RAIS, 2009; EPA, 2010).

The petroleum stations are considered major sourcse of BTEX and carbonyl compounds. These compounds can be generated from the process of importing, 
exporting petrol or emissions from vehicles in or out of fuel stations. Although this source is not continuous and scattered, it is difficult to manage and collect. Workers working at petrol stations are sometimes not equipped with full protective gear and can be in direct contact with these toxic gases through inhalation. The concentration of pollutants and the frequency of exposure will directly affect the level of health risk for those who work at the gasoline stations. According to the statistics of Vietnam National Petroleum Group (Petrolimex), as of November 30, 2015, there were more than 14,000 petrol stations operating throughout the country. The average number of workers is 2-4 for small petrol stations and an average of 4-6 workers in larger stations. Petroleum retail business has created jobs for more than 56,000 workers and occupies an important role in Vietnam's labor market. Health risk for workers at gasoline stations have been studied in several countries around the world (Kitwattanavong, 2010; Tunsaringkarn et al., 2014; Kanjanasiranont, 2015), however, there has not been much research in Vietnam. This study was conducted to assess the health risk for workers exposed to toxic gases such as BTEX, formaldehyde and acetaldehyde at the gasoline stations. Safety concentrations for these compounds would be also proposed utilizing health risk equations.

\section{MATERIALS AND METHODS}

Data collection: In this study, concentrations of BTEX, formaldehyde and acetaldehyde at the gasoline stations were extracted from the the published papers for estimating health risk. The summary of the toxic gases concentrations and its sources were presented in Table 1 .

Table 1. Concentrations of BTEX and cacbonyl compounds at gasoline stations

\begin{tabular}{|c|c|c|c|c|c|}
\hline \multirow{2}{*}{ No. } & \multirow{2}{*}{ Substances } & \multicolumn{3}{|c|}{ Concentration $\left(\mu \mathrm{g} / \mathrm{m}^{3}\right)$} & \multirow{2}{*}{ References } \\
\hline & & Min & Max & Mean & \\
\hline \multirow[t]{5}{*}{1} & Benzene & 12.40 & 357.5 & - & Dutta et al. (2009) \\
\hline & & 95.47 & 262.90 & - & Kitwattanavong (2010) \\
\hline & & - & - & 144.5 & de Oliveira et al. (2007) \\
\hline & & - & - & 60.03 & Xiong et al. (2016) \\
\hline & & 30.27 & 72.44 & $46.13 \pm 13.25$ & Tunsaringkarn et al. (2014) \\
\hline \multirow[t]{5}{*}{2} & Toluene & 12.47 & 183.0 & - & Dutta et al., 2009 \\
\hline & & 167.74 & $\mathbf{5 7 4 . 1 7}$ & - & Kitwattanavong (2010) \\
\hline & & - & - & 157 & de Oliveira et al. (2007) \\
\hline & & - & - & 317.76 & Xiong et al. (2016) \\
\hline & & 28.72 & 142.17 & $91.10 \pm 33.23$ & Tunsaringkarn et al. (2014) \\
\hline \multirow[t]{5}{*}{3} & Ethylbenzene & 2.16 & 156.5 & - & Dutta et al. (2009) \\
\hline & & 24.61 & 73.48 & - & Kitwattanavong (2010) \\
\hline & & - & - & 35.8 & de Oliveira et al. (2007) \\
\hline & & - & - & 113.85 & Xiong et al. (2016) \\
\hline & & 2.05 & 5.91 & $4.55 \pm 1.25$ & Tunsaringkarn et al. (2014) \\
\hline \multirow[t]{9}{*}{4} & m,p-xylene & 4.57 & 141.1 & - & Dutta et al. (2009) \\
\hline & & 46.71 & 218.40 & - & Kitwattanavong (2010) \\
\hline & & - & - & 123.2 & de Oliveira et al. (2007) \\
\hline & & - & - & 98.42 & Xiong et al. (2016) \\
\hline & o-xylene & 2.36 & 77.04 & - & Dutta et al. (2009) \\
\hline & & 17.59 & 75.13 & - & Kitwattanavong (2010) \\
\hline & & - & - & 46.7 & de Oliveira et al. (2007) \\
\hline & & - & - & 37.18 & Xiong et al. (2016) \\
\hline & Xylenes & 43.26 & 67.19 & $58.27 \pm 7.55$ & Tunsaringkarn et al. (2014) \\
\hline \multirow[t]{3}{*}{5} & Formaldehyde & 3.64 & 61.84 & - & Dutta et al. (2009) \\
\hline & & 5.31 & 15.12 & - & Kitwattanavong (2010) \\
\hline & & 3.96 & 153.93 & $11.98 \pm 2.18$ & Tunsaringkarn et al. (2014) \\
\hline \multirow[t]{3}{*}{6} & Acetaldehyde & 4.18 & 27.83 & - & Dutta et al. (2009) \\
\hline & & 1.27 & 7.29 & - & Kitwattanavong (2010) \\
\hline & & 2.02 & 22.91 & $5.85 \pm 1.21$ & Tunsaringkarn et al. (2014) \\
\hline
\end{tabular}

Health risk assessment: Health risk assessment was conducted in accordance with guidelines of the United States Federal Environmental Protection Agency (US. EPA).

Cancer risk is calculated using Equation (1):

$$
\text { Life time cancer risk }=C D I \times S F(1)
$$

In which, $\mathrm{SF}$ is slope factor $(\mathrm{mg} / \mathrm{kg} \text {-day })^{-1}, \mathrm{CDI}$ is the daily intake $(\mathrm{mg} / \mathrm{kg} \mathrm{BW}$-day). If the cancer risk is greater than $10^{-6}$, the carcinogenic effect is unacceptable; conversely, if the cancer risk is less than or equal to $10^{-6}$, the risk is acceptable.

Chronic Daili Intake is calculated based on Equation (2)

$$
C D I=\frac{C A \times I R \times E T \times E F \times E D}{B W \times A T}
$$


In which, $\mathrm{CA}$ is the concentration of pollutants in the air $\left(\mu \mathrm{g} / \mathrm{m}^{3}\right)$; IR is the intensity of air absorption into the body $\left(\mathrm{m}^{3} /\right.$ day); ET is the exposure time (hours/day); $\mathrm{EF}$ is the frequency of exposure (day/year); ED is the exposure period (years); BW is body weight $(\mathrm{kg})$; AT is the average exposure time (days).

Non-cancer risk is calculated based on Equation (3):

$$
H I=\frac{E C}{R f C}
$$

Where $\mathrm{HI}$ is the hazard index; $\mathrm{EC}$ is the exposure concentration $\left(\mathrm{mg} / \mathrm{m}^{3}\right)$ and $\mathrm{RfC}$ is the reference concentration $\left(\mathrm{mg} / \mathrm{m}^{3}\right)$. If $\mathrm{HI}>1$, the risk seriously affects health; in contrast, $\mathrm{HI} \leq 1$, has no serious health effects predicted. However, risks can still exist but just cannot be calculated.

Exposure concentration is calculated based on Equation (4)

$$
E C=\frac{C A \times E T \times E F \times E D}{A T}
$$

In which, EC is concentration of exposure $\left(\mathrm{mg} / \mathrm{m}^{3}\right)$; $\mathrm{CA}$ is the concentration of contaminants in the air $\left(\mathrm{mg} / \mathrm{m}^{3}\right)$; ET is the exposure time (hours/day); EF is the frequency of exposure (day/year); ED is the exposure period (years); AT is the average exposure time (hours).

\begin{tabular}{|c|c|c|c|c|c|c|c|c|c|c|}
\hline & \multirow[t]{2}{*}{ Substance } & \multirow{2}{*}{$\begin{array}{l}\mathrm{RfC} \\
\left(\mathrm{mg} / \mathrm{m}^{3}\right)\end{array}$} & \multirow{2}{*}{$\begin{array}{l}\text { SF } \\
(\mathrm{mg} / \mathrm{kg} \cdot \mathrm{d} a \mathrm{y})^{-1}\end{array}$} & \multirow{2}{*}{$\begin{array}{l}\text { IR } \\
\left(\mathrm{m}^{3} / \mathrm{h}\right)\end{array}$} & \multirow{2}{*}{$\begin{array}{l}\text { ET } \\
\text { (hour/day) }\end{array}$} & \multirow{2}{*}{$\begin{array}{l}\text { EF } \\
\text { (day/year) }\end{array}$} & \multirow{2}{*}{$\begin{array}{l}\text { ED } \\
\text { (year) }\end{array}$} & \multicolumn{2}{|c|}{$\mathrm{CDI}(\mathrm{mg} / \mathrm{kg}$ BW-day } & \multirow{2}{*}{$\begin{array}{l}\mathrm{EC}\left(\mu \mathrm{g} / \mathrm{m}^{3}\right) \\
\mathrm{AT} \text { (hours) }\end{array}$} \\
\hline & & & & & & & & $\begin{array}{l}\text { BW } \\
(\mathrm{kg})\end{array}$ & AT (day) & \\
\hline 1 & Benzene & $3 \times 10^{-2 n}$ & $2.73 \times 10^{-2}$ & $1.125^{\circ}$ & 8 & 350 & 30 & 58.8 & 25,550 & 262,800 \\
\hline 2 & Formaldehyde & - & $2.1 \times 10^{-312}$ & & & & & & & - \\
\hline 3 & Ethylbenzene & - & $3.85 \times 10^{-34}$ & & & & & & & \\
\hline 4 & Acetadehyde & - & $10^{-25}$ & & & & & & & \\
\hline 5 & Toluene & $5^{i}$ & - & & & & & - & & 262,800 \\
\hline 6 & Xylene & $0.1^{\mathrm{e}}$ & - & & & & & & & 262,800 \\
\hline
\end{tabular}

Table 2. Values and coefficients used for calculation of health risk

* Workers averagely inhale $9 \mathrm{~m}^{3}$ of air per working day (Jafari \& Ebrahimi, 2007); ${ }^{a}$ The Risk Asessment Information System (RAIS) (2009)

${ }^{b}$ Office of Environmental Health Hazard Assessment (OEHHA) (2003); ${ }^{c}$ Integrated Risk Information System (IRIS) (2010)

\section{RESULTS AND DISCUSSION}

Concentrations of BTEX and carbonyl compounds: Concentrations of toxic gases in the air from the previous studies were summarized and presented in Table 1. The table indicated the concentration of benzene in the air ranged from $12.40-357.5 \mu \mathrm{g} / \mathrm{m}^{3}$. The mean concentration of benezene in the air ranging from 24.97 to $79.18 \mu \mathrm{g} / \mathrm{m}^{3}$ (Dutta et al., 2009). The benzene concentration measured in three Chinese cities ranged from 15.4 to $67.3 \mu \mathrm{g} / \mathrm{m}^{3}$ ) (Wang et al., 2002). Compared with the limit value of the chemicals in the working air according to Decision No. $3733 / 2002 / Q D-B Y T$, the concentration of benzene surveyed was within the permitted limit $\left(<5 \mathrm{mg} / \mathrm{m}^{3}\right)$. The concentration of toluene in the air ranged from 12.47 to $574.17 \mu \mathrm{g} / \mathrm{m}^{3}$ (Table 1) and met the permitted standard regulated in the Decision No. 3733/2002/QDBYT $\left(<100 \mathrm{mg} / \mathrm{m}^{3}\right)$. The highest concentration was reported in inner Bangkok, Thailand (Kitwattanavong, 2010) which is 46 times higher than the lowest toluene concentration measured at night in Kolkata, India (Dutta et al., 2009). The mean concentration of toluene in the air in Bangkok was $302.64 \mu \mathrm{g} / \mathrm{m}^{3}$ which is higher than the average concentration of benzene $\left(166.23 \mu \mathrm{g} / \mathrm{m}^{3}\right), \quad \mathrm{m}, \quad$ p-xylene $\left(111.27 \mu \mathrm{g} / \mathrm{m}^{3}\right)$, ethylbenzene $\left(44.72 \mu \mathrm{g} / \mathrm{m}^{3}\right)$ and o-xylene (38.83 $\mu \mathrm{g} / \mathrm{m}^{3}$ ) (Kitwattanavong, 2010). Ethylbenzene concentrations was previously reported ranged from
2.05 to $156.5 \mu \mathrm{g} / \mathrm{m}^{3}$ (Dutta et al., 2009; Tunsaringkarn et al., 2014). Up to now, the permissible limit of ethylbenzene in the working air space has not been regulated under Decision 3733/2002/QD-BYT. However, the ethylbenzene concentration collected was satisfactory compared to the regulatory limit according to the United States Occupational Safety and Health Administration ( $<100$ ppm) (OSHA, 1988). Concentrations of $\mathrm{m}, \mathrm{p}$-xyelene and o-xylene in the previous studies ranged from 4.57 to $218 \mu \mathrm{g} / \mathrm{m} 3$ and from 2.36 to $77.04 \mu \mathrm{g} / \mathrm{m}^{3}$. Compared to the Decision No. 3733/2002/QD-BYT, these concentrations were within the allowable limits $(<100$ $\mathrm{mg} / \mathrm{m}^{3}$ ). While $\mathrm{m}, \mathrm{p}$-xylene concentrations in the air was measured low in Kolkata, India (Dutta et al., 2009), the highest concentration was reported in Bangkok, Thailand (Kitwattanavong, 2010). Similar to benzene, the largest fluctuating concentration of oxylene in the air was recorded in Kolkata, India (Dutta et al., 2009).

The lowest formaldehyde concentration in the air was $3.64 \mu \mathrm{g} / \mathrm{m}^{3}$ (Dutta et al., 2009) and the highest was $153.93 \mu \mathrm{g} / \mathrm{m}^{3}$ (Tunsaringkarn et al., 2014). The highest concentration of formaldehyde was measured at roads in Bangkok, Thailand. The mean concentration of formaldehyde in the air measured was $11.98 \mu \mathrm{g} / \mathrm{m}^{3}$ (Tunsaringkarn et al., 2014). However, 
compared with Decision 3733/2002/QD-BYT, these concentrations do not exceed the regulatory limit $(<0.5$ $\left.\mathrm{mg} / \mathrm{m}^{3}\right)$. The concentration of acetaldehyde in the air ranged from 1.27 to $27.83 \mu \mathrm{g} / \mathrm{m}^{3}$ (Dutta et al., 2009; Kitwattanavong, 2010). According to Circular 10/2019-BYT on the allowed exposure value for 50 chemical elements at the workplace, this concentration of acetaldehyde met the prescribed standard $(<1$ $\mathrm{mg} / \mathrm{m}^{3}$ ). According to the report of Dutta et al. (2009), formaldehyde and acetaldehyde were two common carbonyl compounds in the air accounting for $29 \%$ and $21 \%$, respectively of the total concentration of 15 carbonyl compounds. In general, the concentration values of BTEX and carbonyl compounds did occur and highly varied according to time and places. This variation can be explained by the flow of fuel, the number of vehicles entering and leaving the gas station, meteorological conditions at each study sites such as wind direction, seasonal variations (Kitwattanavong, 2010). The occurrence of these toxic gases at the workplaces could result in serious health impact for Vietnamese gasoline station workers if the exposure is long and protective measures are not appropriate. Thus, health risk assessment is urgently needed.

Health Risk Assessment: Carcinogenic risk: The calculated cancer risk for workers working at gasoline stations due to exposure to benzene, ethylbenzene, formaldehyde and acetaldehyde concentrations were shown in Table 3 . The results showed life time cancer risk for workers who may have long-term exposure to benzene in the workplace is unacceptable because the risk value ranged from $2.13 \times 10^{-5}$ to $6.14 \times 10^{-4}$ which is greater than the acceptable value of $10^{-6}$ set by U.S EPA. The calculated risk showed that the highest probable risk is that for every 100,000 workers there will be likely 61 who are at high risk for benzenerelated cancers. Former study also reported that life time cancer risk due to benzene exposure at the gasoline stations in Bangkok, Thailand ranged from $4.14 \times 10^{-5}$ to $4.99 \times 10^{-4}$ (Kitwattanavong, 2010) which was lower than the current study. Cancer risk for petrol station workers is higher than that for other workers such as security guards $\left(3.14 \times 10^{-5}\right)$, street vendors $\left(6.24 \times 10^{-6}\right)$ since these people have less exposure time than the workers work directly at gasoline stations (Tunsaringkarn et al., 2014). The results of life time cancer risk for workers due to exposure to ethylbenzene in the air at petrol stations ranged from $4.96 \times 10^{-7}-3.79 \times 10^{-5}$. For most of the ethylbenzene concentrations collected in the air from the previous studies, the cancer risk for workers at gasoline stations was greater than $10^{-6}$, which could mean that health impact of this pollutant is worrisome. At the highest risk level, four out of every 100,000 workers working there will have a high ethylbenzene-related cancer risk. This life time cancer risk calculated for ethylbenzene in this study was higher than that for petrol station workers in Bangkok $\left(1.26 \times 10^{-5}\right)$ (Kitwattanavong, 2010). The average cancer risk for outdoor workers exposed to ethylbenzen was $2.11 \times 10^{-7}$ (Tunsaringkarn et al., 2014) which was lower than the risk for gas station workers calculated in this study.

Table 3. Life time cancer risk due to exposure to toxic gasses

\begin{tabular}{|c|c|c|c|c|c|}
\hline \multirow{2}{*}{$\begin{array}{l}\text { Data used for risk } \\
\text { calculation from }\end{array}$} & \multirow{2}{*}{ Conc. } & \multicolumn{4}{|c|}{ Cancer risk } \\
\hline & & Benzene & Ethylbenzene & Formaldehyde & Acetaldehyde \\
\hline \multirow{3}{*}{ Dutta et al. (2009) } & Min & $2.13 \times 10^{-5}$ & $5.23 \times 10^{-7}$ & $4.81 \times 10^{-6}$ & $2.63 \times 10^{-6}$ \\
\hline & Max & $6.14 \times 10^{-4}$ & $3.79 \times 10^{-5}$ & $8.12 \times 10^{-5}$ & $1.75 \times 10^{-5}$ \\
\hline & Avg. & - & - & - & - \\
\hline \multirow{3}{*}{$\begin{array}{l}\text { Kitwattanavong } \\
\text { (2010) }\end{array}$} & Min & $1.64 \times 10^{-4}$ & $5.96 \times 10^{-6}$ & $7.01 \times 10^{-6}$ & $7.99 \times 10^{-7}$ \\
\hline & Max & $4.51 \times 10^{-4}$ & $1.78 \times 10^{-5}$ & $2.00 \times 10^{-5}$ & $4.59 \times 10^{-6}$ \\
\hline & Avg. & - & - & - & - \\
\hline \multirow{3}{*}{$\begin{array}{l}\text { de Oliveira et al. } \\
(2007)\end{array}$} & Min & - & - & - & - \\
\hline & Max & - & - & - & - \\
\hline & Avg. & $2.48 \times 10^{-4}$ & $8.67 \times 10^{-6}$ & - & - \\
\hline \multirow{3}{*}{ Xiong et al. (2016) } & Min & - & - & - & - \\
\hline & Max & - & - & - & - \\
\hline & Avg. & $1.03 \times 10^{-4}$ & $2.76 \times 10^{-5}$ & - & - \\
\hline \multirow{3}{*}{$\begin{array}{l}\text { Tunsaringkarn } \\
\text { al. (2014) }\end{array}$} & Min & $5.20 \times 10^{-5}$ & $4.96 \times 10^{-7}$ & $5.23 \times 10^{-6}$ & $1.27 \times 10^{-6}$ \\
\hline & Max & $1.24 \times 10^{-4}$ & $1.43 \times 10^{-6}$ & $2.03 \times 10^{-4}$ & $1.44 \times 10^{-5}$ \\
\hline & Avg. & $7.92 \times 10^{-5}$ & $1.10 \times 10^{-6}$ & $1.58 \times 10^{-5}$ & $3.68 \times 10^{-6}$ \\
\hline
\end{tabular}

The findings in this study indicated that workers at gasoline stations were at risk of cancer due to exposure to formaldehyde and acetaldehyde with the risk values ranged from $4.81 \times 10^{-6}$ to $2.03 \times 10^{-4}$ and from $7.99 \times 10^{-}$ ${ }^{7}$ to $1.75 \times 10^{-5}$, respectively. With the currently existing concentrations of these two carbonyl compounds in the air, the calculated life time cancer risk is always greater than the accepatble level of $10^{-6}$. In the most serious case, 2 in 10,000 workers and 2 in 100,000 will be at risk of cancer due to exposure to formaldehyde and acetaldehyde. Our findings presented that workers at gasoline stations are at risk of cancer due to exposure to benzene, ethylbenzene, formaldehyde and 
acetaldehyde compounds in the air. Strict protective measures should be equipped for the workers.

Non-carcinogenic risk: Table 4 demonstrated the results of calculating health risk for workers at the gasoline stations due to exposure to non-carcinogenic substances. Benzene is also considered as noncarcinogenic chemical. The hazard index for workers' health at petrol stations due to long-term exposure to benzene ranged from 0.13 to $3.81 .50 \%$ of the results calculated hazard index had the hazard index $>1$, which means that the presence of benzene in the air has the potential to seriously affect health. This result is larger than the average hazard index for outdoor workers exposed to benzene in Bangkok, Thailand $\left(9.43 \times 10^{-2}\right)$ (Tunsaringkarn et al., 2014). In addition, the health hazard indexes due to exposure to toluene, $\mathrm{m}$, p-xylene and o-xylene compounds ranged from $7.97 \times 10^{-4}$ to 0.04 , from 0.01 to 0.70 and from 0.01 to 0.25 , respectively. Overall, these results indicated that the risk of these compounds posing to the health of workers working at petrol stations is not serious. However, risks can still exist. This result is similar to the calculated risk result for outdoor workers in Thailand (Tunsaringkarn et al., 2014).

Table 4. Hazard index for the selected toxic gases

\begin{tabular}{|c|c|c|c|c|c|}
\hline \multirow{2}{*}{$\begin{array}{l}\text { Data used for risk } \\
\text { calculation from }\end{array}$} & \multirow{2}{*}{ Conc. } & \multicolumn{4}{|c|}{ Hazard index (HI) } \\
\hline & & Benzene & Toluene & m,p-xylene & o-xylene \\
\hline \multirow{3}{*}{ Dutta et al. (2009) } & Min & 0.13 & $7.97 \times 10^{-4}$ & 0.01 & 0.01 \\
\hline & Max & 3.81 & 0.01 & 0.45 & 0.25 \\
\hline & Avg. & - & - & - & - \\
\hline \multirow{3}{*}{$\begin{array}{l}\text { Kitwattanavong } \\
(2010)\end{array}$} & Min & 1.02 & 0.01 & 0.15 & 0.06 \\
\hline & Max & 2.08 & 0.04 & 0.70 & 0.24 \\
\hline & Avg. & - & - & - & - \\
\hline \multirow{3}{*}{$\begin{array}{l}\text { de Oliveira et al. } \\
(2007)\end{array}$} & Min & - & - & - & - \\
\hline & Max & - & - & - & - \\
\hline & Avg. & 1.54 & 0.01 & 0.39 & 0.15 \\
\hline \multirow{3}{*}{ Xiong et al. (2016) } & Min & - & - & - & - \\
\hline & $\operatorname{Max}$ & - & - & - & - \\
\hline & Avg. & 0.64 & 0.02 & 0.31 & 0.12 \\
\hline \multirow{3}{*}{$\begin{array}{l}\text { Tunsaringkarn et } \\
\text { al. (2014) }\end{array}$} & Min & 0.32 & $1.84 \times 10^{-3}$ & - & - \\
\hline & Max & 0.77 & 0.01 & - & - \\
\hline & Avg. & 0.49 & 0.01 & - & - \\
\hline
\end{tabular}

Total risk: The results of summarizing health risks for both carcinogens and non-carcinogens were listed in Table 5. In general, the total cancer risk for workers at petrol stations ranged from $2.74 \times 10^{-5}$ to $8.72 \times 10^{-4}$ and above the EPA acceptance limit $\left(10^{-6}\right)$. Without proper protective measures, in the most severe case, there will have 87 out of 100,000 people working at petrol stations are at risk of cancer. In addition, the total hazard index due to exposure to non-carcinogenic compounds of workers ranged from 0.15 to 4.8 and it is 4 times higher than the safety threshold for health $(\mathrm{HI}=1)$. The main cause of a high hazard index is the potential for serious health effects from exposure to benzene in the workplace.

Table 5. Summary of the calculated risk

\begin{tabular}{llllll}
\multicolumn{5}{c}{ Table 5. Summary of the calculated risk } \\
\hline \multirow{2}{*}{ No } & \multirow{2}{*}{ Substance } & Cancer risk & \multicolumn{2}{c}{ Non-cancer risk } \\
\cline { 3 - 6 } & & Min & Max & Min & Max \\
\hline 1 & Benzene & $2.13 \times 10^{-5}$ & $6.14 \times 10^{-4}$ & 0.13 & 3.81 \\
2 & Toluene & - & - & $7.97 \times 10^{-4}$ & 0.04 \\
3 & Formaldehyde & $4.81 \times 10^{-6}$ & $2.03 \times 10^{-4}$ & - & - \\
4 & Acetaldehyde & $7.99 \times 10^{-7}$ & $1.75 \times 10^{-5}$ & - & - \\
5 & m,p-xylene & - & - & 0.01 & 0.70 \\
6 & o-xylene & - & - & 0.01 & 0.25 \\
7 & Ethylbenzene & $4.96 \times 10^{-7}$ & $3.79 \times 10^{-5}$ & - & - \\
Total & & $\mathbf{2 . 7 4 \times 1 0 ^ { - 5 }}$ & $\mathbf{8 . 7 2 \times 1 0 ^ { - 4 }}$ & $\mathbf{0 . 1 5}$ & $\mathbf{4 . 8}$ \\
\hline
\end{tabular}

Health risk assessment for the current threshold limits of the toxic gasses in Vietnamese regulations: The results of health risk calculated based on the current values specified in Decision No. 3733/2002/QD-BYT and Circular No. 10/2019/TT-BYT were presented in Table 6 . Based on the concentration limits specified in the current regulations of Decision No. 3733/2002/QD-BYT and Circular No. 10/2019/TT-
BYT, the results of cancer risk due to benzene, formaldehyde and acetaldehyde exposure were $8.59 \times 10^{-3}, 6.60 \times 10^{-4}$ and $6.29 \times 10^{-4}$, respectively; the health hazard index caused by benzene, toluene and xylene were 53.27, 6.39 and 319.63, respectively. As could be seen that workers' health risk when exposed to regulation levels of carcinogens or non-carcinogens in the workplace were several times higher than the 
EPA recommended thresholds $\left(\leq 10^{-6}\right.$ for substances carcinogenic and $\leq 1$ for non-carcinogenic substances). This means that the current values in the regulations of Decision No. 3733/2002/QD-BYT and Circular No. 10/2019/TT-BYT potentially cause serious harm on human health in the workplances. Based on risk calculation formulas and recommended values of cancer risk and hazard index of EPA, the newly recommended values for benzene, toluene, ethylbenzene, xylene, formaldehyde and acetaldehyde shoul be $5.82 \times 10^{-4}, 15.64,4.13 \times 10^{-3}, 0.31,7.57 \times 10^{-4}$ and $1.59 \times 10^{-3} \mathrm{mg} / \mathrm{m}^{3}$, respectively to ensure healthy workplace environment.

Table 6. Risk calculation for values of the toxic gasses in Vietnamese standards

\begin{tabular}{|c|c|c|c|c|c|}
\hline \multirow[b]{2}{*}{ No. } & \multirow[b]{2}{*}{ Substance } & \multirow{2}{*}{$\begin{array}{l}\text { Current values in } \\
\text { the regulations } \\
\left(\mathrm{mg} / \mathrm{m}^{3}\right)\end{array}$} & \multicolumn{2}{|l|}{ Risk* } & \multirow{2}{*}{\begin{tabular}{l}
\multicolumn{2}{l}{ Recommended } \\
new values \\
$\left(\mathrm{mg} / \mathrm{m}^{3}\right)$
\end{tabular}} \\
\hline & & & Cancer & Non-cancer & \\
\hline 1 & Benzene & 5 & $8.59 \times 10^{-3}$ & 53.27 & $5.82 \times 10^{-4}$ \\
\hline 2 & Toluene & 100 & - & 6.39 & 15.64 \\
\hline 3 & Formaldehyde & 0.5 & $6.60 \times 10^{-4}$ & - & $7.57 \times 10^{-4}$ \\
\hline 4 & Acetaldehyde & 1 & $6.29 \times 10^{-4}$ & - & $1.59 \times 10^{-3}$ \\
\hline 5 & Xylene & 100 & - & 319.63 & 0.31 \\
\hline 6 & Ethylbenzene & N/A & - & - & $4.13 \times 10^{-3}$ \\
\hline
\end{tabular}

Conclusion: Concentrations of BTEX and carbonyl compounds were detected in the air at the gasoline stations including benzene, toluene, ethylbenzene, $\mathrm{m}$, p-xylene, o-xylene, formaldehyde and acetaldehyde. The overall risk calculation results revealed that that life time cancer risk as well as non-cancer risk for the workers at the gasoline stations due to exposure to BTEX, formaldehyde and acetaldehyde compounds are really dangerous. The protective measures should be strictly mandatory to the workers working at the gasoline stations.

\section{REFERENCES}

de Oliveira, K; Martins, EM; Arbilla, G; Gatti, LV (2007). Exposure to volatile organic compounds in an ethanol and gasoline service station. Bull. Environ. Contam. Toxicol. 79(2), 237-241.

Dutta, C; Som, D; Chatterjee, A; Mukherjee, AK; Jana, TK; Sen, S (2009). Mixing ratios of carbonyls and BTEX in ambient air of Kolkata, India and their associated health risk. Environ. Monit. Assess. 148(1-4), 97-107.

Jafari, HR; Ebrahimi, S (2007). A study on risk assessment of benzene as one of the VOCs air pollution. Int. J. Environ. Res. 1(3), 214-217.

Kanjanasiranont, N. (2015). Health risk assessment of carbonyl compounds and btex among highly exposure workers in the inner city of Bangkok. Chulalongkorn University,

Kitwattanavong, M (2010). Inhalation exposure to carbonyl compounds and BTEX and health risk assessment of gas station workers in Bangkok metropolitan. Master Thesis, Chulalongkorn University.
Kandyala, R; Phani, S; Raghavendra, C; Rajasekharan, ST (2010). Xylene: An overview of its health hazards and preventive measures. J. Oral. Maxillofac. Pathol. 14(1): 1-5.

Occupational Safety and Health Administration (1988). Ethylbenzene. Retrieved from https://www.cdc.gov/niosh/pel88/100-41.html. Accessed date 010/4/2020.

Possanzini, M; Di Palo, V; Cecinato, A (2002). Sources and photodecomposition of formaldehyde and acetaldehyde in Rome ambient air. Atmos. Environ. 36 (19), 3195-3201.

Vietnam National Petroleum Group (Petrolimex) (2020). https://www.petrolimex.com.vn. Accessed date 01/04/2020.

Rana, SVS; Verma, Y (2005). Biochemical Toxicity of Benzene. J. Environ. Biol. 26, 2: 157-168.

The Risk Asessment Information System (RAIS) (2009). Toxicity Profiles. Retrieved from https://rais.ornl.gov/tox/profiles/Benzene ragsa.h tml. Accessed date 01/04/2020.

Tunsaringkarn, T; Prueksasit, T; Morknoy, D; Siriwong, W; Kanjanasiranont, N; Semathong, S; Zapaung, K (2014). Health risk assessment and urinary biomarkers of VOCs exposures among outdoor workers in urban area, Bangkok, Thailand. Int. J. Environ. Pollut. Solut. 2, 32-46.

United States Environmental Protection Agency (US. EPA) (2010). Human health risk assessment.

Vinh, TH; Xuan, VT; Hai, DT; Huy, DQ; Huan, NX (2017). Assessment of health risks related to 
respiratory exposure to BTEX in the air at intersections in the inner city of Hanoi. Environ. Earth Sci. 33(2017), 229-234.

Wang, X M; Sheng, GY; Fu, JM; Chan, CY; Lee, SG; Chan, LY; Wang, ZS (2002). Urban roadside aromatic hydrocarbons in three cities of the Pearl River Delta, People's Republic of China. Atmos. Environ. 36(33), 5141-5148.
Xiong, F; Li, Q; Zhou, B; Huang, JL; Liang, GQ; Zhang, L; Zou, YF (2016). Oxidative Stress and Genotoxicity of Long-Term Occupational Exposure to Low Levels of BTEX in Gas StationWorkers. Int. J. Environ. Res. Public Health. 13(12), 1-9.

Yardley-Jones, A; Anderson, D; Parke, DV (1991). The Toxicity of Benzene and Its Metabolism and Molecular Pathology in Human Risk Assessment. Br. J. Ind. Med. 48(7), 437-444 